\title{
THE ROLE OF WOMEN EMPOWERMENT TOWARDS HOUSEHOLD POVERTY REDUCTION: EVIDENCE FROM PUNJAB, PAKISTAN Ambreen Sarwar ${ }^{1 *}$, Mumtaz Anwar Chaudhry ${ }^{2}$ \\ ${ }^{1 *}$ Lecturer, School of Economics, University of the Punjab, Lahore, Pakistan; ${ }^{2}$ Professor, School of Economics, University of the Punjab, Lahore, Pakistan. \\ Email: ${ }^{1 *}$ ambreen.eco@pu.edu.pk, ${ }^{2}$ mumtaz.anwar.eco@pu.edu.pk
} Article History: Received on $13^{\text {th }}$ April 2021, Revised on $7^{\text {th }}$ May 2021, Published on $18^{\text {th }}$ May 2021

\section{Abstract}

Purpose of the study: This study intends to examine the impact of various dimensions of women empowerment on multiple constituents of household poverty in the three cities (Lahore, Multan and, Rawalpindi) of province Punjab, Pakistan.

Methodology: The primary data was gathered from a sample of 2400 married and employed females belonging to the three cities of Punjab, Pakistan. For analysis, the study develops its own all-embracing Women Empowerment and Household Poverty variables using exploratory factor analysis (EFA) and confirmatory factor analysis (CFA) and examines the relationship between the empowerment of women and household poverty using structural equation modeling (SEM).

Main Findings: The results show that women empowerment positively and significantly contributes towards household poverty reduction.

Applications of this study: Since poverty is one of the greatest challenges that Pakistan is facing today, the need to change poor standards of living and inspiring women to contribute effectively to society through their active participation in the development process is the dire need of time. The results of the study suggest that in addition to targeting poverty directly, policies should be devised that eradicate poverty through the empowerment of women.

Novelty/Originality of this study: The majority of the past studies have limited generalizability because they use already available surveys/published data, having limited dimensions/indicators of women empowerment and household poverty. Moreover, the past studies that have examined the phenomenon of women empowerment ignore its psychological dimensions. Therefore, because of minimal comprehensive investigation, the examination of the effect of the empowerment of women on household poverty remains a topic of interest for the researchers.

Keywords: Women Empowerment, Household Poverty, Confirmatory Factor Analysis (CFA), Exploratory Factor Analysis (EFA), Structural Equation Modeling (SEM).

\section{INTRODUCTION}

One of the most researched and debated topics for researchers in the field of development is related to the concept of women empowerment. Researchers suggest that women empowerment is important for alleviating poverty and ensuring sustainable economic growth, particularly in developing countries (Akhter \& Cheng, 2020; Hanmer \& Klugman, 2016; Klasen \& Lamanna, 2009). Empowerment is the process of allowing enough independence to an individual or group of individuals so that they can freely make their own choices and work towards achieving their goals (Pratto, 2016).

This capacity-building then contributes towards numerous development outcomes including household poverty reduction (Abrar-ul-Haq, Jali, \& Islam, 2018; Berg \& Ostry, 2017). Past literature suggests that women's economic, familial, psychological, and socio-cultural empowerment affect the education acquiring prospects as well as health and living standards of women and their families which, in turn, contribute towards the development and prosperity of the economy (Alano \& Hanson, 2018; Becker, 2009; Bharadwaj, Fenske, Kala, \& Mirza, 2020; Bueno \& Morefield, 2017; Desai \& Alva, 1998; Duncan, Ziol-Guest, \& Kalil, 2010; S. Rahman, Junankar, \& Mallik, 2009). Therefore, the present research is based on the examination of the role of women empowerment in household poverty alleviation in Punjab, Pakistan.

Poverty has been one of the biggest challenges that Pakistan has been facing. Although the poverty rates in Pakistan have declined over the past few years, millions of people are still living in poverty (Sheikh, 2020). Moreover, women empowerment, which can play a decisive role in alleviating poverty, is also extremely low in Pakistan. Estimates show that the headcount ratio of multidimensional poverty in Pakistan was 38.3\% for the year 2017-18 ((Programme, 2019)and that for the province Punjab was $31.4 \%$ for the year 2014-15.

The statistics for the headcount ratio of multidimensional poverty indicate the gravity of poverty status in Pakistan, and to help ease the stranglehold of poverty in Pakistan, the majority of the country's population must be economically active and capable enough to play a significant role in alleviating poverty. As constitute almost half of the total population of Pakistan, their role can be valuable if they become capable enough to become a significant part of the economy (Khaliq, Khan, Akbar, Hamayun, \& Ullah, 2017; Ojediran \& Anderson, 2020). However, reviewing the current situation of women in Pakistan, it is evident that the country has badly failed to maintain gender justice (Ahmed, 2018) 
Women in Pakistan are often being discriminated and their role in the development of the economy is largely undermined. According to the Gender Inequality Index (GII), which reflects inequalities between males and females based on of health, economic activity, and empowerment, Pakistan ranks 136 out of 162 countries in the 2018 index, scoring as low as 0.547 (UNDP, 2019). Hence, if the country is to improve its economic situation and has to alleviate poverty, there is an increasingly growing need for women empowerment and gender agnostic opportunities for personal growth.

While considering household poverty and well-being, the role of women has irrefutable significance (Abrar-ul-Haq et al., 2018; Islam, 2012) If women are empowered, they have a greater degree of self-reliance and economic agency within their families (Efobi, Tanankem, \& Asongu, 2018). Moreover, the empowerment of women also enables them to help their families in earning their living, raising their standards of living, and upbringing their children in a better way (Heckert, Olney, \& Ruel, 2019). Working women use their earnings to fulfill their families' necessities like food, healthcare, clothing, and education. By this, they can provide them a better standard of living and pull them out of poverty (Duncan et al., 2010; Opoku-Ware, 2014; Revenga \& Shetty, 2012). In this regard, Kabeer and Mahmud (2004) point out that although the majority of the female export processing zones workers in Dhaka have fewer children, they still allocate $13 \%$ of their income towards the school fee of their children.

Other than the monetary contribution of women towards improving health, education, and the standard of living of households, empowered women also make non-monetary contributions as well towards various dimensions of household poverty. Better educated, more aware, and knowledgeable women and the ones that have greater decision making power can ensure proper health care and nutrition for their children, better hygiene conditions, fitness for their families, and an overall improved standard of living (Al-shami, Razali, \& Rashid, 2018; Duncan et al., 2010; Furuta \& Salway, 2006).

Considering the contrary view, researchers are also of the opinion that since working women have less time to give to their families, this at times, negatively affects children and other family members. Since working women increasingly rely on daycare centres or other domestic help, their families lack their attention and experience many undesirable effects on health and the education of children in particular (Azid, Aslam, \& Chaudhary, 2001). Evidence also shows that increased development of women may provide them more opportunities for gender discrimination in the form of giving preference to sons over daughters (Thomas, Contreras, \& Frankerberg, 2002). This discrimination pushes females into deeper poverty and deprives them of education, better health care, and other facilities of life.

Therefore, since the effect empowerment of women on household poverty can both be positive and negative, our key challenge is to create such an environment where women empowerment can positively contribute towards multidimensional aspects of household poverty and its unfavorable effects can be mitigated.

\section{The objective of the study}

This study intends to examine the impact of various dimensions of women empowerment on multiple constituents of household poverty in the three cities (Lahore, Multan and, Rawalpindi) of province Punjab, Pakistan.

\section{LITERATURE REVIEW}

A large body of literature presents evidence related to the women empowerment-poverty link. The researchers suggest that women's economic, socio-cultural, familial, and psychological empowerment significantly affect household poverty.

Specifically considering the role of economic empowerment in household poverty reduction, the past literature reveals that female's paid work has a noteworthy impact on household poverty and inequality. The studies analyzing the impact of women's employment on households suggest that the former contributes significantly towards improving the living standards of the households (Eika, Mogstad, \& Zafar, 2019; Jain-Chandra, Kochhar, Newiak, Yang, \& Zoli, 2018; Kumar, Dahiya, \& Ratwan, 2019; M. M. Rahman, Khanam, \& Nghiem, 2017). This welfare-enhancing effect is particularly important in the case of poor households where female's income constitutes a significant part of the total household income (Jabeen et al., 2020; Morris, 1990; Swamy, 2014).

In this regard, Stier and Lewin (2002) examine the micro-level and the macro-level impacts of women's employment on poverty. The results of the micro-level analysis reveal that female's employment significantly contributes towards reducing household poverty. While the macro-level analysis reveals that female labor force participation reduces poverty in both female-headed and couple-headed households. Considering the results, the authors propose that encouraging the participation of females in the labor force should be the core of all anti-poverty public policies.

Stressing upon the importance of women's economic and familial empowerment in reducing household poverty, Quisumbing and De La Brière (2000) examine the differential impact of husband and wives' bargaining power on the consumption expenditures in rural households in Bangladesh. The results suggest that the wife's current assets or assets brought to marriage have a positive effect on how much they spend on their children's education and clothing. However, women's assets at marriage have a negative effect on health and recreational expenditures while women's current assets have a negative impact on housing and fuel expenditure share. The positive effect of women's incomes on investment in children is in line with the findings of (Thomas, 1994). 
Following the same lines, Hoddinott and Haddad (1995) show that an increase in wife's share of cash income has a significant and positive impact on expenditure share of food while a negative impact on the clothing of adults and children, meals are eaten out, cigarettes and alcohol. The results suggest that policies aimed at providing additional gender support to women can be implemented to increase the expenditure on food and decrease the spending on cigarettes and alcohol.

Considering the effect of economic empowerment of women on poverty specific to the case of children, several studies show that increased availability of economic resources allows working mothers to positively contribute towards the schooling and well-being of their children (Duncan et al., 2010; Pratley, 2016; Revenga \& Shetty, 2012). In this regard, Mohyuddin and Begum (2013) point out that upon participation in the labor market women increasingly rely on timesaving household appliances and hence, have enough time to pay attention to their children. Dunifon, Kalil, Crosby, and

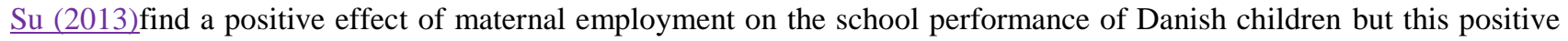
impact is not the result of additional household income. Children's well-being is instead driven by factors such as access to high-quality child care, better mental development, and upbringing by working mothers, and social support provided by employed females. The results of these studies show that women's empowerment is important for improving the education, health, and living standards of households. However, studies (Bernal, 2008; Hsin \& Felfe, 2014; Ruhm, 2008) show that at times, a child's well-being is affected negatively due to the lack of time that working mothers have at their disposal to spend with their children.

Apart from the role that female labor force participation plays in child well-being, public policy discourses increasingly highlight that women's education can play a significant role in lowering infant mortality and improving child health (Bank, 1993; Bharadwaj et al., 2020; Güneș, 2015) Past publications report that maternal empowerment is associated with child health (Alaofè, Zhu, Burney, Naylor, \& Douglas, 2017; Shome, Pal, \& Bharati, 2018; Singh, Bloom, \& Brodish, 2015) Empowered mother can easily move in the society which increases her social networking (Smith, Ramakrishnan, Ndiaye, Haddad, \& Martorell, 2003; Varghese, 2011), access to health care information (Grown, Gupta, \& Pande, 2005; Kurniati, Chen, Efendi, \& Berliana, 2018; Sado, Spaho, \& Hotchkiss, 2014) and access to food and medicines (Mainuddin, Begum, Rawal, Islam, \& Islam, 2015; Shroff et al., 2011).

On the contrary, Preston and Haines (1991) suggest that the role of maternal education in reducing child mortality is not very significant. In developing countries particularly, where there is a dearth of necessities, there is little that educated mothers can do to reduce infant mortality by following a better health care regime.

Stressing upon the importance of women's familial empowerment, Alano and Hanson (2018) point out that through the use of contraceptives women can significantly contribute towards household poverty alleviation. The authors point out that the use of contraceptives helps households to escape the poverty trap in two ways. Firstly, avoidance of unwanted pregnancies/childbirths does not stress the limited household finances. Secondly, by not having to fulfil household responsibilities all day long, women are free to work and contribute towards the household income. The respondents highlighted that the incomes they earn help them to have an improved standard of living. Furthermore, considering women's socio-cultural empowerment, the study participants expressed that the use of contraceptives has improved their and their family's educational status. The participants also highlighted that since education is an influential means for promoting women's empowerment, it has helped them to alleviate individual and household poverty and in turn mitigate livelihood challenges. Similar results are also presented by Shiferaw (2002).

Concluding this review, we can see certain gaps in the literature. Firstly, the majority of the past studies have limited generalizability because they use already available surveys or published data, having limited dimensions of women empowerment and household poverty. There are rarely any studies (as best known to the researcher) that account for the comprehensive nature of the phenomenon of women empowerment and household poverty. Therefore, because of minimal comprehensive investigation, the examination of the effect of women empowerment on household poverty remains a topic of interest for the researchers.

Secondly, the studies that investigate the impact of women empowerment on household poverty do not use any sophisticated techniques. The majority of the studies only use descriptive analysis or chi-square. Therefore, to fill these research gaps, there is a need to conduct a research-based study in Punjab, Pakistan by using more sophisticated and advanced techniques.

\section{Development of variables and hypothesis}

\section{Women Empowerment Variable}

Six dimensions of women empowerment, namely economic, familial, psychological, socio-cultural, political, and legal empowerment, were identified by Malhotra, Schuler, and Boender (2002). Out of these, the first four concern households and communities while the other two operate at the regional or national level. Therefore, since the present study is a household-level study, it only considers economic, familial, psychological, and socio-cultural dimensions of empowerment.

Economic empowerment means women's economic contribution to the well-being of their family as well as their access to and control over their family's assets and income (Malhotra et al., 2002). Familial empowerment implies the 
involvement of a woman in important decision-making within her family, the right to choose her husband and time to get married, control over the marital relationship and family planning as well as protection from domestic violence (Malhotra et al., 2002). Psychological empowerment is a blend of self-efficacy, self-esteem, psychological well-being, and self-awareness (Chhanda \& Dasgupta, 2018; Malhotra et al., 2002). Socio-cultural empowerment refers to the freedom in women's mobility, lack of discrimination against daughters, and a dedication towards educating them (Malhotra et al., 2002).

\section{Household Poverty Variable}

The concept of poverty is complex and a single measure cannot be used to capture this complexity. Therefore, multiple indicators should be used to capture poverty in all its facets. A Multidimensional Poverty Index (MPI), developed by the UNDP, identifies that how, at the individual or household level, people are deprived across three key dimensions: education, health, and the standard of living. Following the basis of MPI, the present study uses education, health, and the standard of living as the key dimensions to measure poverty.

Figure 1 below shows the relationship between Women Empowerment and Household Poverty variables, highlighting the dimensions used for measuring each variable.

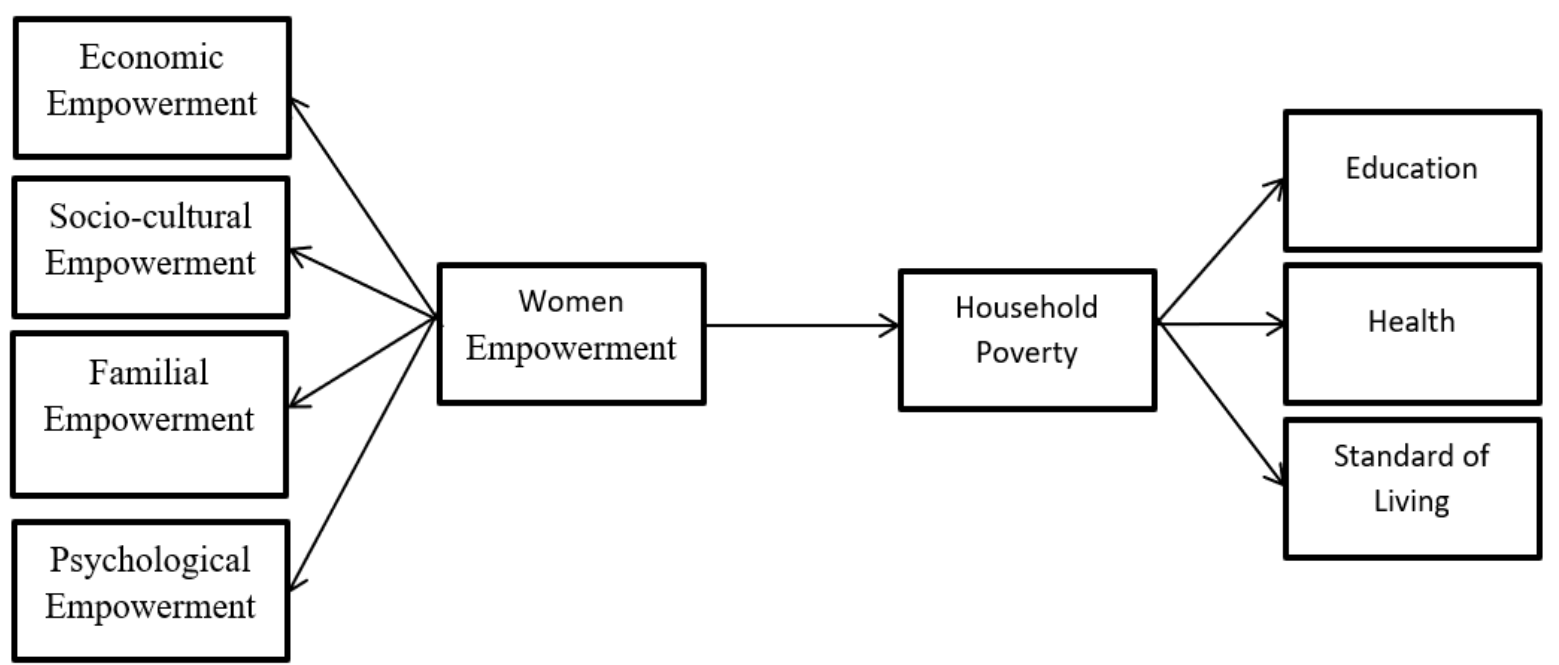

Figure 1: Dimensions for 'Women Empowerment' and 'Household Poverty' Variables

Source: Authors conceptualization

\section{Based on the above discussion, the following relationships are hypothesized:}

$\mathbf{H}_{1 \mathbf{a}}$ : Economic Empowerment is a Factor of Women empowerment.

$\mathbf{H}_{1 \mathbf{b}}$ : Socio-cultural Empowerment is a Factor of Women empowerment.

$\mathbf{H}_{1 \mathbf{c}}$ : Familial Empowerment is a Factor of Women empowerment.

$\mathbf{H}_{\mathbf{1 d}}$ : Psychological Empowerment is a Factor of Women empowerment.

$\mathbf{H}_{\mathbf{2}}$ : Standard of Living is a Factor of Household Poverty.

$\mathbf{H}_{\mathbf{2 b}}$ : Health is a Factor of Household Poverty.

$\mathbf{H}_{2 \mathbf{c}}$ : Education is a Factor of Household Poverty.

$\mathbf{H}_{3}$ : Women Empowerment Significantly Contributes towards Household Poverty Reduction.

\section{METHODOLOGY}

\section{Population, Sampling, and Data Acquisition}

To examine the impact of women empowerment on household poverty, a survey-based study is conducted in Punjab, Pakistan. All cities chosen for the analysis belong to the same province so that factors like cultural variations, that are different across different provinces, can be considered as constant for all respondents. The target population for the present study is the married and employed females of age 18 years or above belonging to the province Punjab, Pakistan. The study uses a multistage sampling method for data collection. In the first stage, the province Punjab is selected from the four provinces of Pakistan. Thereafter, the province Punjab is divided into three regions, namely the Central region, 
Southern region, and Northern region. Then one big city ${ }^{1}$ i.e. Lahore, Multan, and Rawalpindi respectively is selected from each region. Data is collected from each city using disproportionate stratified random sampling with equal allocation. The cities are divided into different strata (towns) and the respondents are selected from each stratum using homogeneous purposive sampling.

A total sample of 2400 is used for the analysis and a survey instrument, consisting of 50 close-ended questions, measured on a Likert scale ranging from Strongly Disagree (1) to Strongly Agree (5), is designed to measure the key variables (Appendix A). The validity and reliability of this survey instrument were checked before estimation. Both paper-pencil-based and web-based surveys were used for data collection. The response rate after cleaning, screening, and removing outliers was $32.083 \%$.

\section{Analysis}

To examine the impact of the empowerment of women on household poverty, the present study has used two higherorder main latent variables namely 'Women Empowerment ' and 'Household Poverty'. These two latent variables are, in turn, measured through several other latent variables. Exploratory factor analysis (EFA) is used to explore the number of factors that determine these latent variables. Only those items are then retained for the further analysis whose factor loadings are greater than 0.30. Tests of Kaiser-Meyer-Olkin (KMO) and Bartlett Sphericity are used to determine the expected level of confidence when running EFA on the data (Hair, Black, Babin, \& Anderson, 2010).

When, based on EFA, a baseline is developed about the relationship between measured variables and items used to measure these variables, SEM is applied in two stages. A confirmatory factor analysis (CFA) is applied in the first stage and the structural model is tested in the second stage. CFA is used to confirm the relationships between the variables and their factor structures. Like EFA, items having factor loadings less than 0.30 are not considered for the analysis. As suggested by Kline (2015) and Williams, Vandenberg, and Edwards (2009), different models fit indices such as Normed Chi-square ( $\mathrm{x}^{2} / \mathrm{df}$ ), CFI, GFI, IFI, RMR, RMSEA, and TLI are used to check the fitness of the measurement models. The values of CFI, GFI, IFI, and TLI must be greater than 0.90 but less than equal to 1 while the value of RMR and RMSEA must be less than 0.08 (Jadoon, Butt, \& Hayat, 2016).

(Fan, Thompson, \& Wang, 1999) Once we confirm the items and the various factors that measure the latent variables of our study, SEM is used to estimate the causal relationship between women empowerment and household poverty.

\section{RESULTS}

\section{Exploratory Factor Analysis (EFA)}

Initially, a total of 33 items were used to measure the 'Women Empowerment ' variable, however, based on the results of EFA, 15 items were not considered for the final analysis because of their low factor loadings or cross-loadings. In the same way, initially, a total of 17 items were considered for the measurement of the 'Household Poverty' variable. Four items were not considered for the final analysis because of their low factor loadings or cross-loadings and a total of 13 items, having factor loadings greater than 0.30 , were considered to measure the 'Household Poverty' variable. Table 1 reports the results of the final EFA.

Table 1: EFA for Women Empowerment and Household Poverty

\begin{tabular}{|c|c|c|c|c|c|}
\hline $\begin{array}{l}\text { Statement } \\
\text { Name }\end{array}$ & Statements & Loadings & $\begin{array}{l}\text { Cronbach's } \\
\text { alpha }(\alpha)\end{array}$ & AVE & CR \\
\hline & Economic Empowerment & & 0.678 & 0.50489 & 0.795903 \\
\hline WEE1 & $\begin{array}{l}\text { Multinational Corporations (MNCs) provide women } \\
\text { with increased job opportunities. }\end{array}$ & 0.806 & & & \\
\hline WEE 2 & $\begin{array}{l}\text { MNCs offer women opportunities for earning higher } \\
\text { pays. }\end{array}$ & 0.767 & & & \\
\hline WEE 3 & $\begin{array}{l}\text { Over the past years, Information Technology (IT) } \\
\text { sector has provided women with increased job } \\
\text { opportunities. }\end{array}$ & 0.768 & & & \\
\hline \multirow[t]{2}{*}{ WEE6 } & $\begin{array}{l}\text { You have control over the purchase of everyday use } \\
\text { items (e.g. grocery, vegetables, clothes, refrigerator, } \\
\text { fans, TV, etc.) required by your household. }\end{array}$ & 0.438 & & & \\
\hline & Socio-cultural Empowerment & & 0.701 & 0.403485 & 0.795256 \\
\hline WESC4 & $\begin{array}{l}\text { Your contribution to household income improves } \\
\text { your relationship with your family members. }\end{array}$ & 0.433 & & & \\
\hline WESC7 & You suffer from violence in public places. & 0.804 & & & \\
\hline
\end{tabular}

${ }^{1}$ The size of the city is determined based on its population, number of educational institutions (school, college, and universities), number of MNCs operating, number of McDonald's, number of cinemas, number of TV sets, and the number of radio transmission hours. 


\begin{tabular}{|c|c|c|c|c|c|}
\hline WESC8 & You lack access to quality health services. & 0.749 & & & \\
\hline WESC9 & You often work under unsafe conditions. & 0.789 & & & \\
\hline \multirow[t]{2}{*}{ WESC11 } & $\begin{array}{l}\text { Women's role as wage earners is considered a threat } \\
\text { to male dominance in households. }\end{array}$ & 0.517 & & & \\
\hline & Familial Empowerment & & 0.761 & 0.513148 & 0.873428 \\
\hline WEF2 & $\begin{array}{l}\text { You are involved in making decisions related to } \\
\text { family planning. }\end{array}$ & 0.769 & & & \\
\hline WEF3 & $\begin{array}{l}\text { You are involved in making decisions to improve } \\
\text { your children's academic performance. }\end{array}$ & 0.896 & & & \\
\hline WEF4 & $\begin{array}{l}\text { You are involved in making decisions to improve } \\
\text { your children's health. }\end{array}$ & 0.934 & & & \\
\hline WEF5 & $\begin{array}{l}\text { You are involved in making decisions to improve } \\
\text { your living standards. }\end{array}$ & 0.547 & & & \\
\hline \multirow[t]{2}{*}{ WEF6 } & $\begin{array}{l}\text { You enjoy more power in your household, regarding } \\
\text { household decisions than the men in the household. }\end{array}$ & 0.311 & & & \\
\hline & Psychological Empowerment & & 0.785 & 0.595478 & 0.854447 \\
\hline WEP1 & You have the opportunity to express yourself freely. & 0.701 & & & \\
\hline WEP2 & $\begin{array}{l}\text { You are satisfied with your role as a woman (e.g. } \\
\text { daughter, mother, or wife). }\end{array}$ & 0.802 & & & \\
\hline WEP3 & $\begin{array}{l}\text { You are satisfied with how you fulfill your } \\
\text { responsibilities. }\end{array}$ & 0.771 & & & \\
\hline \multirow{2}{*}{ WEP4 } & You are independent to make decisions in your life. & 0.808 & & & \\
\hline & Standard of Living & & 0.606 & 0.435305 & 0.718494 \\
\hline HPL1 & $\begin{array}{l}\text { Over the years, you can afford many of those goods } \\
\text { that were previously not affordable. }\end{array}$ & 0.747 & & & \\
\hline HPL2 & $\begin{array}{l}\text { Many goods that previously were affordable to only } \\
\text { a few e.g. mobile phones, laptops, etc. are now } \\
\text { common in most households. }\end{array}$ & 0.675 & & & \\
\hline HPL3 & $\begin{array}{l}\text { Increased competition between companies from all } \\
\text { over the world is reducing the prices of goods and } \\
\text { services. }\end{array}$ & 0.396 & & & \\
\hline HPL6 & Employment is raising your living standard. & 0.497 & & & \\
\hline \multirow[t]{2}{*}{ HPL7 } & $\begin{array}{l}\text { You earn money to maintain a high standard of } \\
\text { living. }\end{array}$ & 0.569 & & & \\
\hline & Health & & 0.609 & 0.455872 & 0.763124 \\
\hline HPH1 & $\begin{array}{l}\text { The use of technology in the field of medicine is } \\
\text { reducing the cost of medical treatments. }\end{array}$ & 0.648 & & & \\
\hline HPH2 & $\begin{array}{l}\text { Children at your home are underweight due to the } \\
\text { lack of availability of healthy food. }\end{array}$ & 0.451 & & & \\
\hline HPH3 & $\begin{array}{l}\text { You have enough money to have healthy food for } \\
\text { your family. }\end{array}$ & 0.759 & & & \\
\hline \multirow[t]{2}{*}{ HPH4 } & $\begin{array}{l}\text { You have easy access to clean drinking water } \\
\text { (filtered or mineral water, etc.). }\end{array}$ & 0.790 & & & \\
\hline & Education & & 0.812 & 0.638574 & 0.874019 \\
\hline HPE1 & $\begin{array}{l}\text { The use of advanced facilities, such as multimedia, } \\
\text { projectors, smart boards, and Wi-Fi in educational } \\
\text { institutions is improving the learning process of the } \\
\text { students. }\end{array}$ & 0.751 & & & \\
\hline HPE3 & $\begin{array}{l}\text { You have enough money to provide education to } \\
\text { your family members. }\end{array}$ & 0.634 & & & \\
\hline HPE4 & $\begin{array}{l}\text { You have enough time for focusing on the education } \\
\text { of your family members. }\end{array}$ & 0.908 & & & \\
\hline HPE5 & $\begin{array}{l}\text { You have enough time for focusing on the } \\
\text { upbringing of your family members. }\end{array}$ & 0.874 & & & \\
\hline
\end{tabular}

The results show that the value of Cronbach's alpha coefficient is greater than 0.60 for all the latent variables. This confirms the internal consistency reliability. Since the present study is using a higher-order model, there is no need to check the discriminant validity. The convergent validity and construct reliability are checked with the help of average variance extracted (AVE) and composite reliability (CR). The values of AVE and CR must be greater than 0.50 and 0.70 respectively (Cropanzano \& Mitchell, 2005). However, convergent validity will still exist if the value of AVE is less 
than 0.50 and $\mathrm{CR}$ is greater than 0.60 (Lam, 2012). Our results, as reported in Table 1, confirm the existence of convergent validity and construct reliability.

\section{Confirmatory Factor Analysis (CFA)}

CFA is performed as a new instrument was developed to check the linkage between women empowerment and household poverty reduction. A higher-order CFA is applied in which all four dimensions of women empowerment are linked to the 'Women Empowerment' variable and the three dimensions of household poverty are linked to the 'Household Poverty' variable. To apply a higher-order CFA, a measurement variable must have at least three first-order variables and each first-order variable must have at least 2 items to measure the variable (Kline, 2005). The goodness of fit indices for CFA is presented in Table 2.

Table 2: Goodness of Fit Indices for CFA

\begin{tabular}{llllllll}
\hline & $\mathbf{x}^{2} / \mathbf{d f}$ & CFI & GFI & IFI & TLI & RMR & RMSEA \\
\hline Women Empowerment & 2.9711 & 0.959 & 0.959 & 0.959 & 0.948 & 0.053 & 0.051 \\
\hline Household Poverty & 2.8535 & 0.952 & 0.974 & 0.952 & 0.934 & 0.041 & 0.049 \\
\hline
\end{tabular}

The values of CFI, GFI, IFI, and TLI for both women empowerment and household poverty are greater than the minimum limit of 0.90. Due to low factor loadings, 3 items for the 'Women Empowerment' construct, namely WEE6, WESC4, and WEF6, and two items for the 'Household Poverty' construct, namely HPL6 and HPH1, are deleted and are not considered for the final analysis.

\section{SEM Analysis}

Since the values of all the fit indices $\left(\mathrm{x}^{2} / \mathrm{df}=2.9328, \mathrm{CFI}=0.912\right.$, GFI $=0.927, \mathrm{IFI}=0.912, \mathrm{TLI}=0.901, \mathrm{RMR}=0.059$, RMSEA $=0.048)$ lie within the desired thresholds level, SEM results show that the model is an excellent fit. The coefficients of various paths in the model are presented in Figure 2.

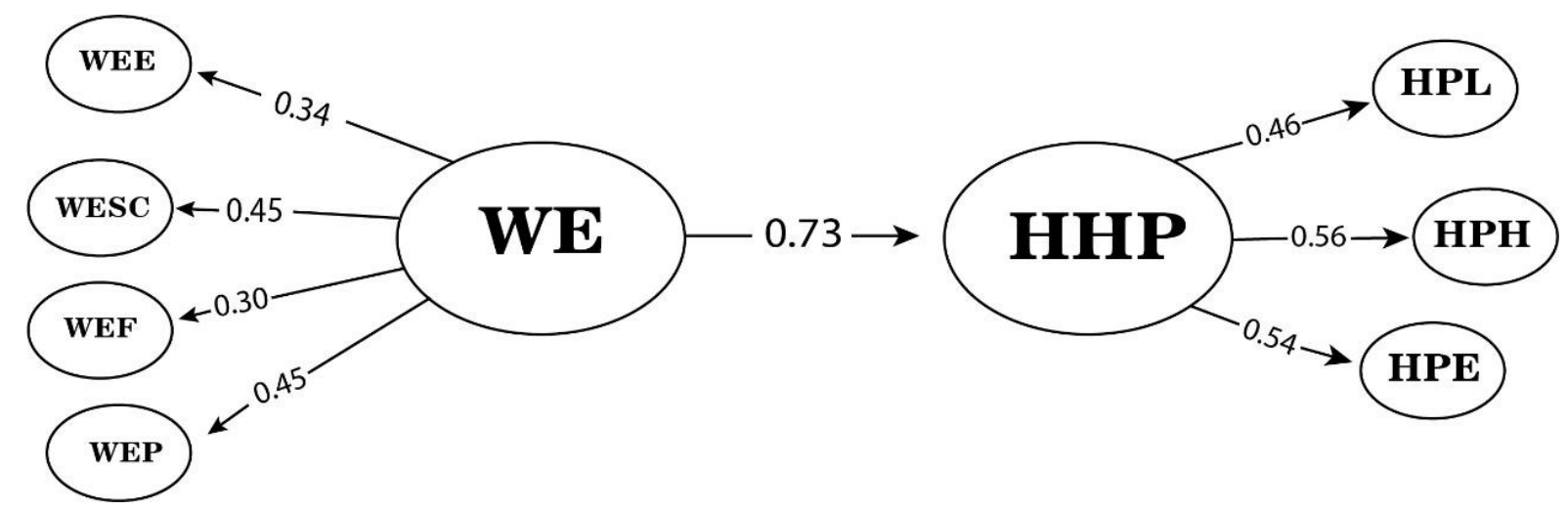

Figure 2: Path Estimates

Figure 2 shows that economic empowerment, socio-cultural empowerment, familial empowerment, psychological empowerment have path coefficient of $0.34,0.45,0.30$ and 0.45 respectively that are significant at $1 \%$ level (p-value < 0.01). The path coefficients indicate that all these four dimensions are a key determinant of women empowerment. These results support the hypotheses $\mathrm{H}_{1 \mathrm{a}}, \mathrm{H}_{1 \mathrm{~b}}, \mathrm{H}_{1 \mathrm{c}}$, and $\mathrm{H}_{1 \mathrm{~d}}$. Moreover, the standard of living, health, and education have path coefficients of $0.46,0.56$, and 0.54 respectively (all are significant at $1 \%$ level (p-value $<0.01$ ). The path coefficients show that all three dimensions are key determinants of household poverty. These results support the hypotheses $\mathrm{H}_{2 \mathrm{a}}, \mathrm{H}_{2 \mathrm{~b}}$, and $\mathrm{H}_{2 \mathrm{c}}$. The results confirm the positive and significant effect of women empowerment on household poverty reduction $(\beta=0.73$, p-value $<0.01)$. Hence the results also support the $\mathrm{H}_{3}$ hypothesis. The details of the hypothesis and related decision are presented in Table 3 .

Table 3: Hypothesis and their related decisions

\begin{tabular}{lccc}
\hline \multicolumn{1}{c}{ Hypotheses } & B & P-value & Result \\
\hline $\begin{array}{l}\text { Economic Empowerment is a Factor of } \\
\text { Women Empowerment. }\end{array}$ & 0.34 & 0.000 & $\mathrm{H}_{1 \mathrm{a}}$ is accepted \\
\hline $\begin{array}{l}\text { Socio-cultural Empowerment is a Factor of } \\
\text { Women Empowerment. }\end{array}$ & 0.45 & 0.000 & $\mathrm{H}_{1 \mathrm{~b}}$ is accepted \\
\hline $\begin{array}{l}\text { Familial Empowerment is a Factor of Women } \\
\text { Empowerment. }\end{array}$ & 0.30 & 0.000 & $\mathrm{H}_{\mathrm{cc}}$ is accepted \\
\hline $\begin{array}{l}\text { Psychological Empowerment is a Factor of } \\
\text { Women Empowerment. }\end{array}$ & 0.45 & 0.000 & $\mathrm{H}_{1 \mathrm{~d}}$ is accepted \\
\hline Standard of Living is a Factor of Household & 0.46 & 0.000 & $\mathrm{H}_{2 \mathrm{a}}$ is accepted \\
\hline
\end{tabular}




\begin{tabular}{llll}
\hline Poverty. & & & \\
\hline Health is a Factor of Household Poverty. & 0.56 & 0.000 & $\mathrm{H}_{2 \mathrm{~b}}$ is accepted \\
\hline Education is a Factor of Household Poverty. & 0.54 & 0.000 & $\mathrm{H}_{2 \mathrm{c}}$ accepted \\
\hline $\begin{array}{l}\text { Women Empowerment Significantly } \\
\text { Contributes towards Household Poverty }\end{array}$ & 0.73 & 0.000 & $\mathrm{H}_{3}$ is accepted \\
Reduction. & & & \\
\hline
\end{tabular}

\section{DISCUSSION}

Over the past few years, the world is increasingly focusing on gender equality, women empowerment, and poverty reduction. These terms have been prominent in the 2030 Agenda for Sustainable Development which envisages a world where no one is left behind and everyone can live up to their full potential.

The results show that the 4 dimensions (economic empowerment, familial empowerment, psychological empowerment, and socio-cultural empowerment) considered for measuring women empowerment variable determine the composite women empowerment variable (hypotheses $\mathrm{H}_{1 \mathrm{a}}, \mathrm{H}_{1 \mathrm{~b}}, \mathrm{H}_{1 \mathrm{c}}$, and $\mathrm{H}_{1 \mathrm{~d}}$ are supported). These results are in line with the study of Malhotra et al. (2002) who identified these 4 dimensions to be the determinants of women empowerment. The findings suggest that the economic empowerment of women is crucial for the overall empowerment of women. Greater access to economic resources and control over income gives women greater independence (Pratto, 2016) and brings modification in the power balance of the families in such a way that women are more empowered and are considered equally responsible for the functioning of the households (Bacchus, 2005). Our results support the economic bargaining theory of family which suggests that an increase in the income of women (economic empowerment) improves their bargaining power and ensures greater empowerment for them within their families (Khan \& Awan, 2011).

The findings also suggest that familial empowerment of women is also an important component of women empowerment. Involvement in decision-making within the family, control over the matrimonial relationship and childbirth, and liberty from household violence improve women's social and economic position in society. The results suggest that freedom in physical movement (for acquiring education or for work) and lack of discrimination against females (socio-cultural empowerment) is essential for women empowerment. Women are empowered when they are encouraged to acquire education and work. Dasgupta (2003) points out that positive attitudinal changes towards women's role in the family are witnessed when women acquire better quality education and work at reputable positions. Education enables women to improve their socio-economic status and makes them more capable of protecting their rights. Lastly, the findings also suggest that psychological empowerment is another salient determinant of the empowerment of women. There is only sparse evidence in the empirical literature on the role of psychological empowerment as a key component of the overall empowerment of women. Brockner (1988) and Spreitzer (1995) show that self-esteem helps to promote women's empowerment at their workplace. $\underline{\text { Bandura (1977) }}$ also highlights that people having high self-esteem are expected to perform efficiently.

Our findings also show that the three dimensions (education, health, and the standard of living) used for measuring household poverty determine the composite household poverty variable (hypotheses $\mathrm{H}_{2 \mathrm{a}}, \mathrm{H}_{2 \mathrm{~b}}$, and $\mathrm{H}_{2 \mathrm{c}}$ are supported). These results are in line with the idea of poverty put forward by the World Bank (2001). The people living below the poverty line are not able to enjoy basic needs, like essential nourishment, a reasonable standard of living, basic health, and education (Janjua \& Kamal, 2014).

A plethora of studies have highlighted the significance of education for overall household poverty reduction (Awan, Malik, Sarwar, \& Waqas, 2011; Geda, De Jong, Mwabu, \& Kimenyi, 2001). These studies suggest that education is an important determinant of poverty because it affects poverty in multiple ways. Firstly, education enhances an individual's productivity which helps him to find better employment opportunities, improves his earnings, and pulls him out of poverty (Barro, 1991; Janjua \& Kamal, 2014; Mankiw, Romer, \& Weil, 1992; Romer, 1990; Saravanakumar, 2020). Secondly, education, and especially better quality education, contributes towards the development of the economy which, in turn, brings a lot of economic opportunities that raise the income of the households. Lastly, the impact of education on poverty works through several indirect channels (externalities) as well e.g. through the impact of education on the ability to make better decisions, reduced fertility, and infant mortality (Janjua \& Kamal, 2014).

Another crucial determinant of household poverty is the health of the individuals who belong to a specific household. Poverty and poor health worldwide are inextricably linked. People who are deprived of good health are deemed poor. People who do not have access to health care services or do not have information or money to access health care services are not able to treat or prevent diseases. As a result, these people live in vulnerable conditions. Since good health is a prerequisite for increasing an individual's productivity, poor health reduces an individual's productivity and, in turn, his income (Bloom \& Canning, 2003; Gounder \& Xing, 2012). Therefore, as health is considered central to household wellbeing, health is an important component of household poverty.

Apart from health and education, and overall standard of living that an individual has is a key constituent of household poverty. Improving the living conditions of the people is what poverty reduction is all about. Raising the standards of 
living of households boosts the overall well-being of societies. Access to basic amenities of life allows individuals to thrive and societies to flourish.

Stressing upon the relationship between the empowerment of women and household poverty, our findings suggest that women empowerment positively contributes towards household poverty reduction. Empowerment of women can play a crucial role in reducing the stranglehold of multiple aspects of household poverty in Punjab, Pakistan. Women's economic, familial, psychological, and socio-cultural empowerment helps to improve their and their families living standards, which, in turn, can contribute towards the development and prosperity of the economy. If women have more power, autonomy, and a voice in society they are in a position to provide a better standard of living to their families and drive them out of poverty. These results are in line with the ones presented by (Bharadwaj et al., 2020); Bueno and Morefield (2017); Duncan et al. (2010), Mohyuddin and Begum (2013), Morris (1990), Opoku-Ware (2014), Revenga and Shetty (2012) and Stier and Lewin (2002).

Our findings suggest that when considering household poverty and well-being, the role of women has irrefutable significance. A greater degree of self-reliance and economic agency within their families allows women to make significant monetary and non-monetary contributions to their families. Empowered women are better able to contribute towards the education, upbringing, health, and the overall standard of living of their families (Brooks-Gunn \& Duncan, 1997; Kabeer \& Mahmud, 2004). Empowering women, giving them decision-making power, and allowing them free involvement can go a long way in reducing poverty and improving the overall standard of living at the family and community level. Our results suggest that empowerment of women can bring lasting changes for the women and these changes go hand and hand with improvements for everyone.

\section{CONCLUSION AND RECOMMENDATIONS}

The present study examines the impact of various dimensions of women empowerment on multiple constituents of household poverty. For analysis, questionnaires were sent to 2400 married and employed females belonging to the three big cities of Punjab, Pakistan. Using EFA and CFA the study develops composite measures for 'Women Empowerment' and 'Household Poverty' and then investigates the underlying relationship between the empowerment of women and household poverty using SEM. Our findings suggest that the empowerment of women can indeed help reduce household poverty in a lot of different ways. Moreover, the results also suggest that the effect of women empowerment is more intense on the education and health dimension of household poverty.

Considering the results of the study and acknowledging the significance of women empowerment in alleviating poverty and the development of the economy, there are some important policy recommendations. Since poverty is one of the greatest challenges that Pakistan is facing today, the need to change poor standards of living and inspiring women to contribute effectively to society through their active participation in the development process is the dire need of time. Therefore, in addition to targeting poverty directly, policies should be devised that eradicate poverty through the empowerment of women. Although the role of government and other institutions in empowering women is very vital, empowering women should not only be the concern of the government. Women themselves should be active agents in their empowerment process. Therefore, apart from the direct cash transfers, the policies that intend to provide basic vocational skills or training to women, and those that provide awareness to women on their rights should be the focus of the government of Punjab, Pakistan. These help to empower women and as a result, reduce household poverty. In this regard, Women's centers (an initiative launched under the Ehsaas framework) established in Azad Kashmir and Northern areas of Pakistan are providing free training on cutting, sewing, knitting, and embroidery to the marginalized women groups. There is, however, a need to introduce such programs on a large scale so that more women living in various areas of Pakistan can benefit from such initiatives. The focus of the policymakers should be to developing well-planned literacy and life-skills programs for women to increase their awareness about the core issues of life and sufficiently empower them so that they can contribute towards household poverty alleviation.

In this era of globalization, media and technology can also play a significant role in empowering women and reducing poverty. Media and technology can provide awareness on women's rights and focus on increasing public recognition of the potential of women empowerment for the development of a country. This will ensure that there are no gender-biased practices and society as a whole contributes towards the empowerment of women. Moreover, media and Information and Communication Technology (ICT) can also help spread information about various employment opportunities and skill development programs offered for women. This will simultaneously empower women and help in poverty alleviation.

Therefore, for the eradication of poverty through women empowerment, a comprehensive strategy is required. Investing in human resources, developing infrastructure (for setting up women and centers training institutes), although important, are only some components of this strategy that should be supplemented with additional policies for women empowerment and household poverty alleviation.

\section{Limitations and Suggestions}

The current research only collects data from a limited number of respondents (321 valid questionnaires) due to financial and time constraints. Moreover, only three cities are taken to be representative of the province of Punjab. Therefore, to deeply understand the effects of the empowerment of women on household poverty and to analyze the differences 
between and within regions, more cities should be considered for analysis. Furthermore, this study only considers the urban areas of the province Punjab, Pakistan so rural areas should also be considered to generalize the results.

\section{AUTHOR'S CONTRIBUTIONS}

Ambreen Sarwar: Conceptualization, manuscript preparation, formal analysis and application, methodology writing, writing the original draft, and formal analysis.

Mumtaz Anwar Chaudhry: Supervision of the study, Literature Review, Analysis, Policy Implications.

\section{REFERENCES}

1. Abrar-ul-Haq, M., Jali, M., \& Islam, G. (2018). The Development of Household Empowerment Index among Rural Household of Pakistan. Pertanika Journal of Social Sciences \& Humanities, 26(2),787-809.

2. Ahmed, A. (2018). Pakistan among worst performers on gender equality: WEF. Daily dawn. December, 19.

3. Akhter, J., \& Cheng, K. (2020). Sustainable empowerment initiatives among rural women through microcredit borrowings in Bangladesh. Sustainability, 12(6), 2275. https://doi.org/10.3390/su12062275

4. Al-shami, S. S. A., Razali, R., \& Rashid, N. (2018). The effect of microcredit on women empowerment in welfare and decisions making in Malaysia. Social Indicators Research, 137(3), 1073-1090. https://doi.org/10.1007/s11205-017-1632-2

5. Alano, A., \& Hanson, L. (2018). Women's perception about contraceptive use benefits towards empowerment: A phenomenological study in Southern Ethiopia. PLoS One, 13(9), e0203432. https://doi.org/10.1 371/journal.pone.0203432

6. Alaofè, H., Zhu, M., Burney, J., Naylor, R., \& Douglas, T. (2017). Association between women's empowerment and maternal and child nutrition in Kalale District of northern Benin. Food and nutrition bulletin, 38(3), 302-318. https://doi.org/10.1177/0379572117704318

7. Awan, M. S., Malik, N., Sarwar, H., \& Waqas, M. (2011). Impact of education on poverty reduction. International Journal of Academic Research, 3 (1),659-664.

8. Azid, T., Aslam, M., \& Chaudhary, M. O. (2001). Poverty, female labour force participation, and cottage industry: a case study of cloth embroidery in rural Multan. The Pakistan Development Review, 1105-1118. https://doi.org/10.30541/v40i4IIpp.1105-1118

9. Bacchus, N. (2005). The effects of globalization on women in developing nations. Honors College Theses, 2.

10. Bandura, A. (1977). Self-efficacy: toward a unifying theory of behavioral change. Psychological review, 84(2), 191. https://doi.org/10.1037/0033-295X.84.2.191

11. Bank, W. (1993). World Development Report 1993: Investing in Health., Volume 1. The World Bank.

12. Barro, R. J. (1991). Economic growth in a cross section of countries. The quarterly journal of economics, 106(2), 407-443. https://doi.org/10.2307/2937943

13. Becker, G. S. (2009). Human capital: A theoretical and empirical analysis, with special reference to education: University of Chicago press.

14. Berg, A. G., \& Ostry, J. D. (2017). Inequality and unsustainable growth: Two sides of the same coin? IMF Economic Review, 65(4), 792-815. https://doi.org/10.1057/s41308-017-0030-8

15. Bernal, R. (2008). The effect of maternal employment and child care on children's cognitive development. International Economic Review, 49(4), 1173-1209. https://doi.org/10.1111/j.1468-2354.2008.00510.x

16. Bharadwaj, P., Fenske, J., Kala, N., \& Mirza, R. A. (2020). The Green revolution and infant mortality in India. Journal of health economics, 71, 102314. https://doi.org/10.1016/j.jhealeco.2020.102314

17. Bloom, D., \& Canning, D. (2003). The health and poverty of nations: from theory to practice. Journal of Human Development, 4(1), 47-71. https://doi.org/10.1080/1464988032000051487

18. Brockner, J. (1988). Self-esteem at work: Research, theory, and practice: Lexington Books/DC Heath and Com.

19. Brooks-Gunn, J., \& Duncan, G. J. (1997). The effects of poverty on children. The future of children, 55-71. https://doi.org/10.2307/1602387

20. Bueno, N., \& Morefield, R. (2017). Empowerment of Women and Poverty Reduction in Developing Countries. Inquiry, 2(2). https://doi.org/10.21533/isjss.v2i2.80

21. Chhanda, D., \& Dasgupta, C. (2018). The Psychological Aspects of Women Empowerment at Workplace. International Journal of Current Research and Modern Education (IJCRME) Volume, 3.

22. Dasgupta, K. (2003). Globalisation and Indian women: Problems, possibilities and information needs-An Overview. IFLA Women's Issues. Paper presented at the Public Libraries and Information Science Journals Sections Globalisation: Empowering Women through Information. Impact of Information Availability and Use in Society on Women. World Library and Information Congress: 69th IFLA General Conference and Council.

23. Duncan, G. J., Ziol-Guest, K. M., \& Kalil, A. (2010). Early-childhood poverty and adult attainment, behavior, and health. Child development, 81(1), 306-325. https://doi.org/10.1111/j.1467-8624.2009.01396.x

24. Dunifon, R., Kalil, A., Crosby, D. A., \& Su, J. H. (2013). Mothers' night work and children's behavior problems. Developmental Psychology, 49(10), 1874. https://doi.org/10.1037/a0031241 
25. Efobi, U. R., Tanankem, B. V., \& Asongu, S. A. (2018). Female economic participation with information and communication technology advancement: Evidence from Sub-Saharan Africa. South African Journal of Economics, 86(2), 231-246. https://doi.org/10.1111/saje.12194

26. Eika, L., Mogstad, M., \& Zafar, B. (2019). Educational assortative mating and household income inequality. Journal of Political Economy, 127(6), 2795-2835. https://doi.org/10.1086/702018

27. Fan, X., Thompson, B., \& Wang, L. (1999). Effects of sample size, estimation methods, and model specification on structural equation modeling fit indexes. Structural equation modeling: a multidisciplinary journal, 6(1), 56-83. https://doi.org/10.1080/10705519909540119

28. Furuta, M., \& Salway, S. (2006). Women's position within the household as a determinant of maternal health care use in Nepal. International family planning perspectives, 17-27. https://doi.org/10.1363/3201706

29. Geda, A., De Jong, N., Mwabu, G., \& Kimenyi, M. (2001). Determinants of poverty in Kenya: A household level analysis. ISS Working Paper Series/General Series, 347, 1-20.

30. Gounder, R., \& Xing, Z. (2012). Impact of education and health on poverty reduction: Monetary and nonmonetary evidence from Fiji. Economic modelling, 29(3), 787-794. https://doi.org/10.1016/i .econmod.2012.01.018

31. Grown, C., Gupta, G. R., \& Pande, R. (2005). Taking action to improve women's health through gender equality and women's empowerment. The lancet, 365(9458), 541-543. https://doi.org/10.1016/S0140$\underline{6736(05) 17872-6}$

32. Güneş, P. M. (2015). The role of maternal education in child health: Evidence from a compulsory schooling law. Economics of education review, 47, 1-16. https://doi.org/10.1016/j.econedurev.2015.02.008

33. Hair, J. F., Black, W. C., Babin, B. J., \& Anderson, R. E. (2010). Multivariate data analysis: Global edition. UK: Pearson Education Limited.

34. Hanmer, L., \& Klugman, J. (2016). Exploring women's agency and empowerment in developing countries: Where do we stand? Feminist Economics, 22(1), 237-263. https://doi.org/10.1080/13545701.2015.1091087

35. Heckert, J., Olney, D. K., \& Ruel, M. T. (2019). Is Women's Empowerment a Pathway to Improving Child Nutrition Outcomes in a Nutrition-Sensitive Agriculture Program?: Evidence From a Randomized Controlled Trial in Burkina Faso. Social science \& medicine (1982), 233, 93-102. https://doi.org/10.1016/j. socscimed.2019.05.016

36. Hoddinott, J., \& Haddad, L. (1995). Does female income share influence household expenditures? Evidence from Côte d'Ivoire. Oxford Bulletin of Economics and statistics, 57(1), 77-96. https://doi.org/10.1111/j.14680084.1995.tb00028.x

37. Hsin, A., \& Felfe, C. (2014). When does time matter? Maternal employment, children's time with parents, and child development. Demography, 51(5), 1867-1894. https://doi.org/10.1007/s13524-014-0334-5

38. Islam, T. (2012). Microcredit and poverty alleviation: Ashgate Publishing, Ltd.

39. Jabeen, S., Haq, S., Jameel, A., Muhammad Asif, A. H., Hwang, J., \& Jabeen, A. (2020). Impacts of rural women's traditional economic activities on household economy: Changing economic contributions through empowered women in rural Pakistan. Sustainability, 12(7), 2731. https://doi.org/10.3390/su12072731

40. Jadoon, A. K., Butt, A. R., \& Hayat, M. A. (2016). Development of measurement models for globalization, consumption patterns and culture. Pakistan Economic and Social Review, 54(2), 327-361.

41. Jain-Chandra, M. S., Kochhar, M. K., Newiak, M. M., Yang, Y., \& Zoli, M. E. (2018). Gender Equality: Which Policies Have the Biggest Bang for the Buck? International Monetary Fund. https://doi.org/10.5089/9781484353257.001

42. Janjua, P. Z., \& Kamal, U. A. (2014). The Role of Education and Health in Poverty Alleviation a Cross Country Analysis. Journal of Economics, Management and Trade, 896-924. https://doi.org/10.9734/BJEMT/2014/6461

43. Kabeer, N., \& Mahmud, S. (2004). Globalization, gender and poverty: Bangladeshi women workers in export and local markets. Journal of International Development, 16(1), 93-109. https://doi.org/10.1002/jid.1065

44. Khaliq, A., Khan, D., Akbar, S., Hamayun, M., \& Ullah, B. (2017). Female Labor Market Participation and Economic Growth: The Case of Pakistan. Journal of Social Science Studies, 4(2), 217-230. https://doi.org/10.5296/jsss.v4i2.11386

45. Khan, S. U., \& Awan, R. (2011). Contextual assessment of women empowerment and its determinants: Evidence from Pakistan. https://doi.org/10.1080/13545700902893106

46. Klasen, S., \& Lamanna, F. (2009). The impact of gender inequality in education and employment on economic growth: new evidence for a panel of countries. Feminist Economics, 15(3), 91-132.

47. Kline, R. B. (2015). Principles and practice of structural equation modeling: Guilford publications.

48. Kumar, M., Dahiya, S., \& Ratwan, P. (2019). Backyard poultry farming in India: A tool for nutritional security and women empowerment. Biological Rhythm Research, 1-16. https://doi.org/10.1080/09291016.2019.1628396

49. Kurniati, A., Chen, C.-M., Efendi, F., \& Berliana, S. M. (2018). Factors influencing Indonesian women's use of maternal health care services. Health care for women international, 39(1), 3-18. https://doi.org/10. 1080/07399332.2017.1393077

50. Mainuddin, A., Begum, H. A., Rawal, L. B., Islam, A., \& Islam, S. S. (2015). Women empowerment and its relation with health seeking behavior in Bangladesh. Journal of family \& reproductive health, 9(2), 65. 
51. Malhotra, A., Schuler, S. R., \& Boender, C. (2002). Measuring women's empowerment as a variable in international development. Paper presented at the background paper prepared for the World Bank Workshop on Poverty and Gender: New Perspectives.

52. Mankiw, N. G., Romer, D., \& Weil, D. N. (1992). A contribution to the empirics of economic growth. The quarterly journal of economics, 107(2), 407-437. https://doi.org/10.2307/2118477

53. Mohyuddin, A., \& Begum, N. (2013). Changing Role of Women Due to Technology at Household Level: A Case Study of Village Chontra, District Rawalpindi, Pakistan. Stud, 2(3).

54. Morris, L. (1990). The Workings of the Household. Cambridge. Polity.

55. Ojediran, F. O., \& Anderson, A. (2020). Women's Entrepreneurship in the Global South: Empowering and Emancipating? Administrative Sciences, 10(4), 87. https://doi.org/10.3390/admsci10040087

56. Opoku-Ware, J. (2014). Women's productive and economic roles towards household poverty reduction in Ghana: A survey of Bongo District in Northern Ghana. Research on Humanities and Social Sciences, 4(19), 148-155.

57. Pratley, P. (2016). Associations between quantitative measures of women's empowerment and access to care and health status for mothers and their children: a systematic review of evidence from the developing world. Social Science \& Medicine, 169, 119-131. https://doi.org/10.1016/j.socscimed.2016.08.001

58. Pratto, F. (2016). On power and empowerment. British Journal of Social Psychology, 55(1), 1-20. https://doi.org/10.1111/bjso.12135

59. Preston, S. H., \& Haines, M. R. (1991). Front matter, tables of content Fatal Years: Child Mortality in Late Nineteenth-Century America (pp. -23--28): Princeton University Press. https://doi.org/10.1515/9781400861897

60. United Nation Development Programme (2019). Human development report 2019: Beyond income, beyond averages, beyond today: Inequalities in human development in the 21 st century.

61. Quisumbing, A. R., \& De La Brière, B. (2000). Women's assets and intrahousehold allocation in rural Bangladesh: Testing measures of bargaining power(No. 579-2016-39314).

62. Rahman, M. M., Khanam, R., \& Nghiem, S. (2017). The effects of microfinance on women's empowerment: new evidence from Bangladesh. International Journal of Social Economics. https://doi.org/10.1108/IJSE-022016-0070

63. Rahman, S., Junankar, P. N., \& Mallik, G. (2009). Factors influencing women's empowerment on microcredit borrowers: a case study in Bangladesh Development Economics (pp. 205-224): Springer. https://doi.org/10.1057/9781137555229_14

64. Revenga, A., \& Shetty, S. (2012). Empowering Women Is Smart Economics-Closing gender gaps benefits countries as a whole, not just women and girls. Finance and Development-English Edition, 49(1), 40.

65. Romer, P. M. (1990). Endogenous technological change. Journal of Political Economy, 98(5, Part 2), S71S102. https://doi.org/10.1086/261725

66. Ruhm, C. J. (2008). Maternal employment and adolescent development. Labour Economics, 15(5), 958-983. https://doi.org/10.1016/j.labeco.2007.07.008

67. Sado, L., Spaho, A., \& Hotchkiss, D. R. (2014). The influence of women's empowerment on maternal health care utilization: evidence from Albania. Social Science \& Medicine, 114, 169-177. https://doi.org/10.1016/j.s ocscimed.2014.05.047

68. Saravanakumar, A. (2020). Life skill education for creative and productive citizens. Journal of Critical Reviews, 7(9), 554-558. https://doi.org/10.31838/jcr.07.09.110

69. Sheikh, H. (2020). Poverty eradication in Pakistan: past, present, and future. . Retrieved 9/4/2021, 2021, from https://www.theigc.org/blog/poverty-reduction-in-pakistan-past-present-and-future/

70. Shiferaw, B. (2002). Poverty and natural resource management in the semi-arid tropics: Revisiting challenges and conceptual issues: ICRISAT.

71. Shome, S., Pal, M., \& Bharati, P. (2018). Influence of maternal autonomy and socioeconomic factors on birth weight of infants in India. Malaysian Journal of Nutrition, 24(1) 35-46.

72. Shroff, M. R., Griffiths, P. L., Suchindran, C., Nagalla, B., Vazir, S., \& Bentley, M. E. (2011). Does maternal autonomy influence feeding practices and infant growth in rural India? Social Science \& Medicine, 73(3), 447455. https://doi.org/10.1016/j.socscimed.2011.05.040

73. Singh, K., Bloom, S., \& Brodish, P. (2015). Gender equality as a means to improve maternal and child health in Africa. Health care for women international, 36(1), 57-69. https://doi.org/10.1080/07399332.2013.824971

74. Smith, L. C., Ramakrishnan, U., Ndiaye, A., Haddad, L., \& Martorell, R. (2003). The importance of Women's status for child nutrition in developing countries: international food policy research institute (IFPRI) research report abstract 131. Food and nutrition bulletin, 24(3), 287-288. https://doi.org/10.1177/156482650302400309

75. Spreitzer, G. M. (1995). Psychological empowerment in the workplace: Dimensions, measurement, and validation. Academy of management Journal, 38(5), 1442-1465. https://doi.org/10.5465/256865

76. Stier, H., \& Lewin, A. C. (2002). Does women's employment reduce poverty? Evidence from Israel. Work, Employment and Society, 16(2), 211-230. https://doi.org/10.1177/095001702400426811

77. Swamy, V. (2014). Financial inclusion, gender dimension, and economic impact on poor households. World Development, 56, 1-15. https://doi.org/10.1016/j.worlddev.2013.10.019 
78. Thomas, D. (1994). Like father, like son; like mother, like daughter: Parental resources and child height. Journal of Human Resources, 950-988. https://doi.org/10.2307/146131

79. Thomas, D., Contreras, D., \& Frankerberg, E. (2002). Distribution of power within the household and child health. University Library of Munich, Germany.

80. Varghese, T. (2011). Women empowerment in Oman: A study based on women empowerment index. Far East Journal of Psychology and Business, 2(2), 37-53.

81. Williams, L. J., Vandenberg, R. J., \& Edwards, J. R. (2009). 12 structural equation modeling in management research: A guide for improved analysis. Academy of Management Annals, 3(1), 543-604. https://doi.org/10.5465/19416520903065683

\section{Appendix A \\ QUESTIONNAIRE}

Note: Please provide one best-suited response for all questions.
1. Age: $\square 18-25$ years
$\square$ 26-35 years
$\square$ 36-46 years
$\square$ Above 46 years

2. Income (per month in rupees): ----------------

3. Highest degree completed: $\square$ Bachelor

$\square$ Masters

$\square$ M.Phil.

$\square \quad$ Ph.D.

$\square$ Other Please specify-----------------

4. Nature of your job: $\square$ Public $\square$ Private

Respond to the following questions using the rating criteria given below:

1. Strongly Disagree (SD) 2. Disagree (D) 3. No Opinion (N) 4. Agree (A) 5. Strongly Agree (SA)

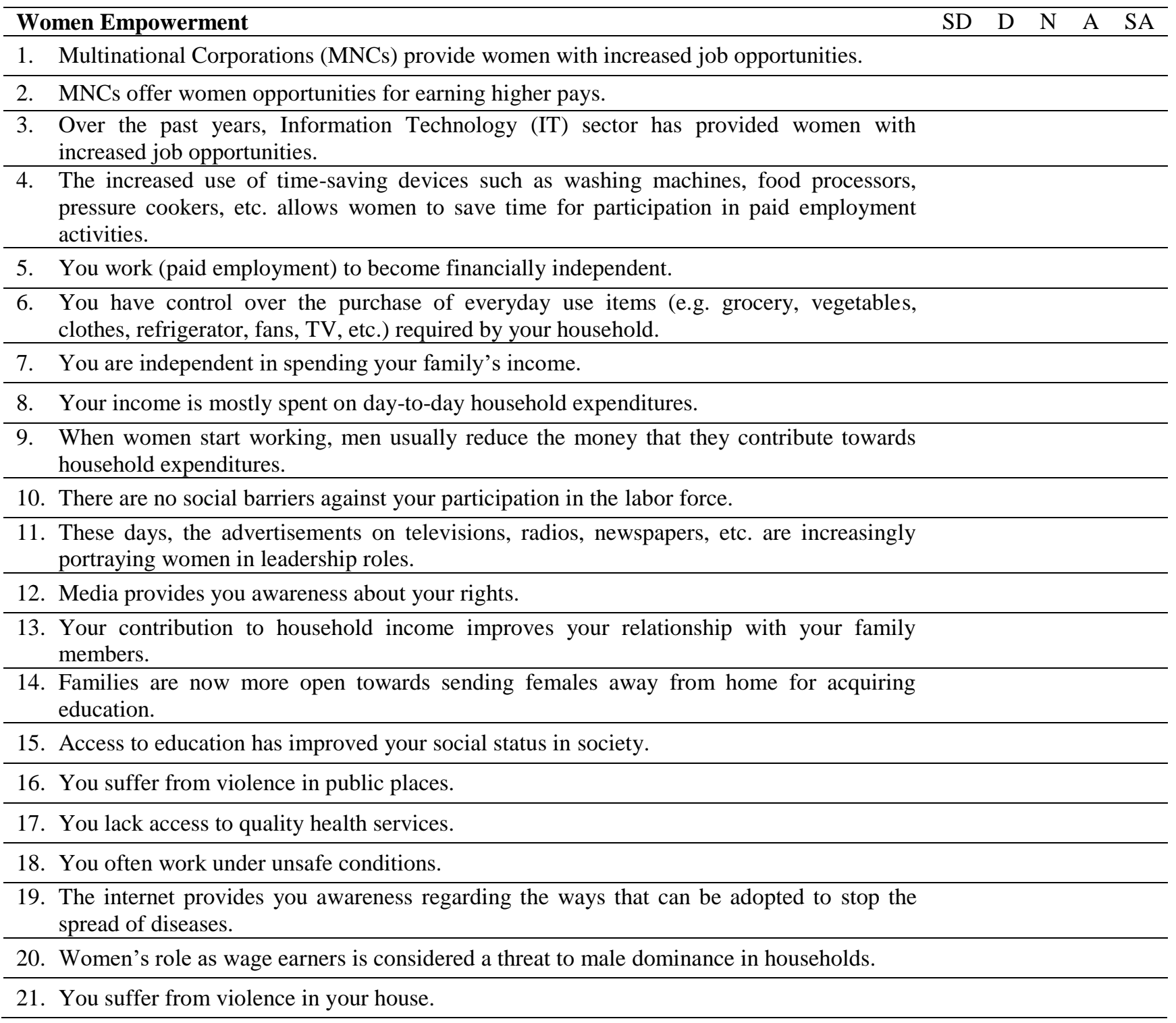


22. You are involved in making decisions related to family planning.

23. You are involved in making decisions to improve your children's academic performance.

24. You are involved in making decisions to improve your children's health.

25. You are involved in making decisions to improve your living standards.

26. You enjoy more power in your household, regarding household decisions than the men in the household.

27. You had the freedom to decide your marriage timing.

28. You had the freedom to select your spouse (husband).

29. You have the opportunity to express yourself freely.

30. You are satisfied with your role as a woman (e.g. daughter, mother, or wife).

31. You are satisfied with how you fulfill your responsibilities.

32. You are independent to make decisions in your life.

33. There are social barriers against your participation in the labou force.

Household Poverty

1. Over the years, you are able to afford many of those goods that were previously not affordable.

2. Many goods that previously were affordable to only a few e.g. mobile phones, laptops, etc. are now common in most households.

3. Increased competition between companies from all over the world is reducing the prices of goods and services.

4. Advancement in technology is reducing the prices of various goods and services.

5. You work primarily to meet the financial needs of your family.

6. Employment is raising your living standard.

7. You earn money to maintain a high standard of living.

8. The use of technology in the field of medicine is reducing the cost of medical treatments.

9. Children at your home are underweight due to the lack of availability of healthy food.

10. You have enough money to have healthy food for your family.

11. You have easy access to clean drinking water (filtered or mineral water, etc.).

12. You have enough time for focusing on the fitness of your family members.

13. The use of advanced facilities, such as multimedia, projectors, smart boards, and Wi-Fi in educational institutions is improving the learning process of the students.

14. The number of Pakistani students going abroad for studies has increased over time.

15. You have enough money to provide education to your family members.

16. You have enough time for focusing on the education of your family members.

17. You have enough time for focusing on the upbringing of your family members. 